\title{
Application of Veterinary Cytogenetics in Domestic Animals: A Review
}

\author{
Muhammad Sanusi Yahaya ${ }^{1,2}$, Mohd Shahrom Salisi ${ }^{3^{*}}$, Nur Mahiza Md. Isa ${ }^{4}$ \\ Abd Wahid Haron ${ }^{1}$ and Innocent Damudu Peter ${ }^{1,5}$ \\ ${ }^{1}$ Department of Clinical Studies, Faculty of Veterinary Medicine, Universiti Putra, Malaysia. \\ ${ }^{2}$ Department of Theriogenology and Animal Production, Faculty of Veterinary Medicine, \\ Usmanu Danfodiyo University, Sokoto, Nigeria. \\ ${ }^{3}$ Department of Preclinical Studies, Faculty of Veterinary Medicine, Universiti Putra, Malaysia. \\ ${ }^{4}$ Department of Pathology and Microbiology, Faculty of Veterinary Medicine, Universiti Putra, \\ Malaysia. \\ ${ }^{5}$ Department of Theriogenology, Faculty of Veterinary Medicine, University of Maiduguri, Maiduguri,
} Nigeria.

Authors' contributions

This work was carried out in collaboration among all authors. All authors read and approved the final manuscript.

Article Information

DOI: 10.9734/ARRB/2019/v33i130112

Editor(s):

(1) Dr. Oluyomi A. Sowemimo, PhD, Department of Zoology, Obafemi Awolowo University, lle-lfe, Osun State, Nigeria. Reviewers:

(1) Alejandra Hernández Ceruelos, Universidad Autónoma del Estado de Hidalgo, México. (2) Oluwole Olufunke Oluwakemi, Institute of Agricultural Training, Nigeria. (3) Kamran Baseer Achakzai, Pakistan. Complete Peer review History: http://www.sdiarticle3.com/review-history/51281

Review Article

Received 04 July 2019

Accepted 07 September 2019

Published 14 September 2019

\begin{abstract}
Cytogenetics is the study of chromosomes; their structure and properties, chromosome behavior during cell division, their influence on traits and factors which cause changes in chromosomes. Veterinary cytogenetics is the application of cytogenetics to clinical problems that occur in animal production. It has been applied to understand problems such as infertility and its types, embryonic and fetal death, abnormality in sexual and somatic development and hybrid sterility and also prenatal sex determination and other forms of chromosomal abnormalities. These are achieved through conventional and banded karyotyping techniques and molecular cytogenetic techniques. Although conventional techniques are still useful and very widely applied, the nature of cytogenetics has gradually changed as a result of advances achieved in the molecular cytogenetic techniques for
\end{abstract}


example fluorescent in situ hybridization and array-based techniques. These changes are evident in both molecular diagnostics and basic research. The combination of conventional and molecular cytogenetics has given rise to high resolution techniques which have enabled the study of fundamental questions regarding biological processes. It enables the study of inherited syndromes, the mechanisms of tumorigenesis at molecular level, genome organization and the determination of chromosome homologies between species. It allows the ease with which animals are selected in breeding programs and other important aspects of animal production. In this paper we discussed a number of techniques employed in cytogenetics and their methodologies, and recommend where future focus should be for the benefits of animal production.

Keywords: Cytogenetics; karyotyping; chromosomal aberrations; in situ hybridization.

\section{INTRODUCTION}

The term cytogenetics has traditionally referred to studies of cellular aspects of heredity, particularly those that bordered on the description of chromosome structures and identification of chromosomal aberrations that cause disease [1]. For various applications, from clinical diagnostics to basic genomic research, cytogenetics has been used in this sense. The term has however been expanding rapidly within the last few decades and currently includes a host of related cytological techniques. Two events that occurred in the mid nineteen sixties, which revolutionized the field of cytogenetics were the report of Gustavsson and Rockborn [2] about the discovery of the Robertsonian translocation in the karyotype of cattle and second was the ability of scientists to describe the effects of such anomaly on the fertility of animal carriers by [3].

The field of cytogenetics is broadly classified into 1) Conventional cytogenetics and 2) Molecular cytogenetics. The conventional techniques comprise the normal chromosome staining and the banding techniques, some of which are $G, Q$, $\mathrm{R}, \mathrm{C}$ and T-banding and NOR staining. These have since been integrated into animal breeding programs to investigate chromosome abnormalities thereby reducing the incidents of reproductive losses in livestock production [4]. This is achieved by subjecting bulls for reproduction to undergo rigorous cytogenetic testing, i.e conventional and banded karyotyping to detect chromosomal anomalies [5]. Various researchers have applied the banding techniques to bring to light the nature of chromosomes and possible homology between different species. lannuzzi [6] described $G$ and $R$ karyotypes of cattle at about 500 band level using a number of standards, i.e Reading Conference standard [7]. They have been able to elucidate the nature of the small acrocentric chromosomes and other disputed chromosomes using some bovid markers. In another leap Di Berardino et al. [8] have, through the molecular techniques, demonstrated homologies between cattle and goat chromosomes 11, 16, 17, 18, 20, 21, 22, 23, 24 and 26, and variations in the remaining autosomes and recommend further investigation of some of the elongated chromosomes. The banding techniques, which were developed in the 1970, which have improved the resolution at which chromosomes are compared between species and even between and within breeds to study homologies, have evolved over time and are still widely used $[1,9,10]$. They have been used in various aspect of domestic animals' improvement, from disease diagnoses to breeding evaluations. Chromosome anomalies are however sometimes too complex for banding techniques to be employed to diagnose them fully. This therefore necessitated the need for more sensitive and more refined techniques. This sensitivity and refinement was achieved through the development of molecular cytogenetics [11].

Molecular cytogenetic techniques on the other hand, provide more opportunities for genome study as they provide higher resolution than the conventional techniques. The techniques started through the development of in situ hybridization (ISH). Over the past three decades the field of molecular cytogenetics has witnessed the birth of techniques with increasingly higher resolutions [1]. The earlier molecular cytogenetic techniques were based on in situ hybridization, where radioactively labelled probes were used as the reporter molecules [12]. These were based on the work of Gall and Pardue [13] who used DNARNA hybridization to localize some genes. Since then, simpler and more efficient probe detection methods have been developed. These include direct and indirect fluorochrome labelling, biotin labelling through Degenerate Oligonucleotide Primed PCR (DOP-PCR) [1], which itself is still being improved [14]. Today a variety of 
molecular cytogenetic techniques, including those initially designed for humans, are applied to domestic animals for various purposes [15]. These methods include but are not limited to micronucleus assay, Comet assay, localization of telomeric sequences and telomere length analysis and are fast becoming part of regular cytogenetic investigative techniques in veterinary research and clinical practice $[15,16,17]$. Here we review some of the important techniques currently applied to the study of domestic animals.

\subsection{Cytogenetics and Domestic Animal Studies}

Conventional cytogenetic techniques have always been a part of veterinary cytogenetics, both in clinical practice and research $[18,19]$, molecular cytogenetics is relatively a recent introduction.

Although the application of molecular cytogenetics is more intense in humans, the number of studies and the complexity of the techniques carried out in domestic animals recently has shown the viability and the promise of the techniques in addressing a lot of biological questions in animals [20,21]. Various aspects of FISH techniques have been applied to veterinary cytogenetics. For instance aneuploidy in porcine embryos was investigated using threecolor fluorescent in situ hybridization (FISH) method using chromosome-specific DNA probes; it enabled the establishment of baseline frequencies of aneuploidy in embryos, spermatozoa and oocytes [22,23]. Another molecular cytogenetic technique, primed in situ DNA synthesis (PRINS), has been applied to pig's genome to visualize the interstitial telomeric signal in the genome. It is an attractive complement to FISH for detection of DNA repetitive sequences and unlike conventional $\mathrm{FISH}$, it displays lower level of non-specific hybridization $[15,21,24,25]$. In the field of in vitro embryo production and other reproductive biotechnologies, cytogenetics in collaboration with other aspects of molecular biology are expected to play vital role in understanding the mechanisms underlying chromosome instability in embryos and the impact of the in vitro environment on embryo's chromosomes [26,27] Researchers have also been working to optimize the hybridization of molecular probes specific to the $X$ chromosomes in mare. Although the success is slow in this regard, the future promise is enormous [28]. Bovine species, which are often considered model animal species have been studied through various aspects of molecular cytogenetic techniques such as SKY/MFISH, linkage studies, FISH-mapping and other relevant techniques [29,30,31]. Cytogenetic studies have shown great usefulness in agriculture and evolutionary biology as they enable researchers the opportunity to understand the origin of domestic species [30]. These techniques have also provided us with some understanding of the effect of domestication on animal behavior [32].

Bugno et al. [32] have used the combination of conventional cytogenetics techniques; silver nitrate staining and molecular cytogenetic techniques; FISH and PRINS to study chromosomal polymorphism in a population of wild and domestic foxes.

Comparative molecular cytogenetics in avian species to improve reproductive capabilities is an emerging area in animal reproduction [33]. As would be expected, different techniques are used to study different aspects of cytogenetics (Table 1).

\section{THE TECHNIQUES}

Some of the various techniques employed in conventional and molecular cytogenetics are discussed briefly in the coming sections below.

\subsection{The Conventional Techniques}

\subsubsection{Peripheral Blood Mononuclear Cells (PBMC) cell culture and metaphase preparation}

$5 \mathrm{mls}$ of whole blood is obtained by means of heparinized vacutainer. PBMCs are obtained either directly from the buffy coat after centrifuging whole blood at $1900 \mathrm{rpm}$ for 8 minutes, or by gradient isolation using Ficoll ${ }^{\circledR}$. They are grown in culture medium: RPMI 1640 medium, supplement: bovine fetal serum, Lglutamine, antibiotics, in the presence of a mitogen (eg Pokeweed, Concanavalin or Phytohemagglutinin). They are generally incubated for 72 hours, one hour before harvest, colcemid at $10 \mu \mathrm{g} / \mathrm{ml}$ is added to stop cell division and arrest the cells at metaphase. The arrested cells are treated with hypotonic solution, $\mathrm{KCl}$, $(0.075 \mathrm{M})$ for $15-20$ mins and the cell are fixed with glacial acetic acid: methanol 1:3 
Yahaya et al.; ARRB, 33(1): 1-16, 2019; Article no.ARRB. 51281

Table 1. Cytogenetics techniques and the chromosome anomaly they identify

\begin{tabular}{|c|c|c|c|c|c|c|c|}
\hline & Polyploidy & Aneuploidy & $\begin{array}{l}\text { Reciprocal } \\
\text { translocation }\end{array}$ & $\begin{array}{l}\text { Unbalanced } \\
\text { translocation }\end{array}$ & $\begin{array}{l}\text { Amplification } \\
\text { (DM or HSR) }\end{array}$ & $\begin{array}{l}\text { Amplification } \\
\text { (distributed insertions) }\end{array}$ & $\begin{array}{l}\text { Cell to cell to } \\
\text { cell variability }\end{array}$ \\
\hline \multicolumn{8}{|l|}{ Detection } \\
\hline \multicolumn{8}{|l|}{ Technique } \\
\hline Banding & + & + & + & + & + & - & + \\
\hline FISH/SKY & + & + & + & + & + & + & - \\
\hline $\mathrm{CGH}$ & - & + & - & + & + & + & + \\
\hline
\end{tabular}




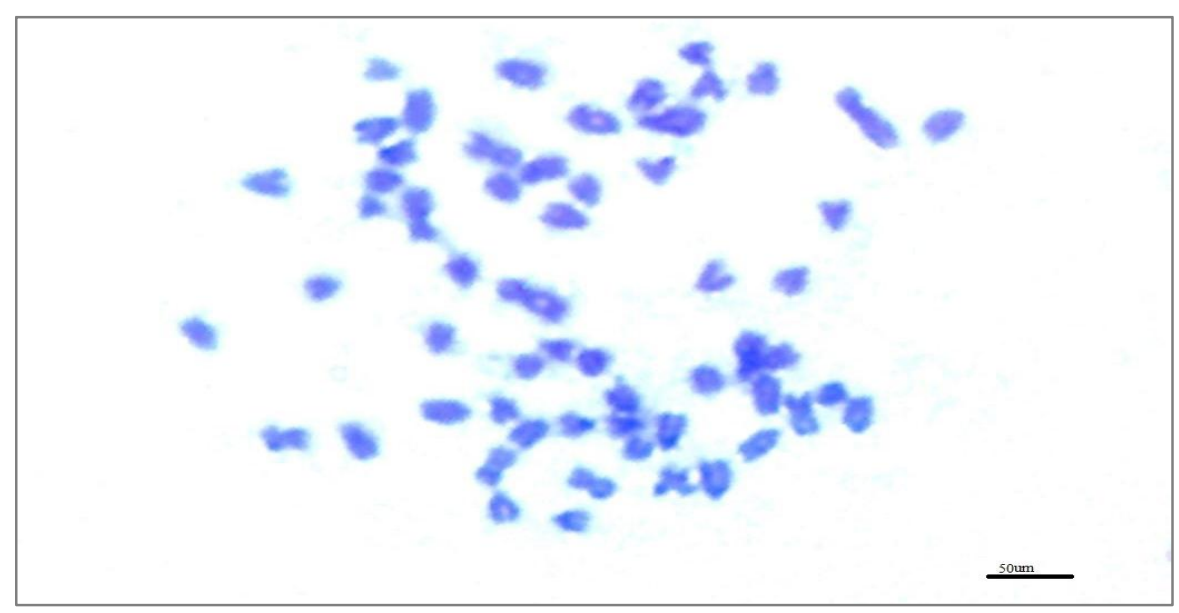

Fig. 1. A metaphase chromosomes spread of the deer (Rusa timorensis) produced for conventional cytogenetics karyotyping

Source: Theriogenology and cytogenetic laboratory UPM, 2019

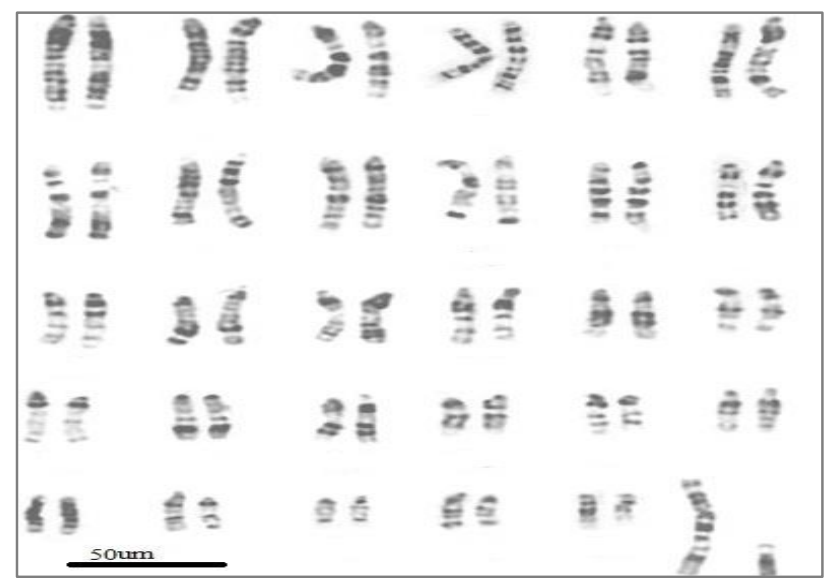

Fig. 2. A G banded karyotype of the domestic cattle (Bos taurus) karyotyping Source: Adopted from lannuzzi (1996)https://www.semanticscholar.org

(Carnoy's fixative). After cell culture, chromosome slides are prepared for downstream studies [9,34-36]. (Fig. 1).

\section{CHROMOSOME BANDING TECHNI- QUES}

\subsection{G banding}

$\mathrm{G}$ banding is a euchromatic banding technique that is essential in individual chromosomes identification. It is used to identify chromosome abnormalities and rearrangements in cancers and genetic diseases [37,38]. The basis of $G$ banding is its ability to differentiates between early euchromatin and late heterochromatin (euchromatin = light bands, heterochromatin = dark bands). For $\mathrm{G}$ banding, slides are aged at room temperature for three or more days. They are thereafter rinsed in distilled water, incubated in $0.025 \%$ freshly prepared trypsin for $35-40$ seconds. They are then rinsed in three washed of $\mathrm{PBS}^{-}$, which blocks the action of trypsin, 2 to $10 \%$ Giemsa is used to stain the slides. They are air dried and viewed under microscope (Fig. 2).

\subsection{R-banding}

R-band is approximately opposite of $\mathrm{G}$ or $\mathrm{Q}$ bands produced by various means and has the theoretical advantage of staining the gene-rich chromatin, thereby enhancing the ability to visualize small structural rearrangements in the parts of the genome that are most likely to result 
in phenotypic abnormalities [38]. R-banding reveals the GC-rich euchromatin and produces positive bands that correspond to the negative of G-bands.

Slides are prepared and aged for three days, they are then incubated in a buffer solution twice, usually Earle's bicarbonate free solution, first at $87^{\circ} \mathrm{C} \mathrm{pH} 5.3$ for 30 minutes, then at $87^{\circ} \mathrm{C}, \mathrm{pH} 6.5$ for another 30 minutes after which they are rinsed in running water. The slides are then stained with Giemsa and viewed under microscope with orange filter.

\subsection{NOR Staining}

Ag-NOR staining is employed to identify the nucleolar organizers and their activities on chromosomes.

The slides are incubated in borate buffer $\mathrm{pH} 9.2$ at room temperature for 30 minutes. They are rinsed in distilled water and then air dried. They are mounted in a $50 \%$ silver nitrate solution with a coverslip. They are put in a humid chamber and incubated in a water bath at $65^{\circ} \mathrm{C}$ for 1 hour. After the incubation, they are rinsed with distilled water and then stained for 1 minute with $1 \%$ Giemsa and observed under microscope. A lot of variant methods can be used for this technique [39,40,41,39-41].

\section{THE MOLECULAR CYTOGENETIC TECHNIQUES}

\subsection{Fluorescent in situ Hybridization (Fish)}

Fluorescence in situ hybridization (FISH) is a technique that allows the localization of genes and other specific DNA sequences on target cells and chromosomes. FISH is widely applied in cytological studies and has gone beyond gene mapping or the study of genetic rearrangements in disease. It is used increasingly used to study genome organization in various organisms including livestock and plant [42,43,44,42-44].

The discovery that labelled ribosomal RNA hybridizes to acrocentric chromosomes was the foundation of the FISH technique (i.e. chromosomes in which the centromere is not located at the center) [45]. In the beginning, radioisotopes were used as reporters for the FISH technique. However, the arrival fluorochromes, which are safer alternatives, both in their time requirement and their ability to give rise to different colours, has provided a suitable replacement. This technique involves the use of DNA or RNA probes, which are labelled with fluorescent molecules and hybridized to genomic DNA sequences, to enable the study of specific sites on chromosomes. It can be used in physical chromosome mapping, chromosomes rearrangement analysis, comparative gene mapping, studies of chromosome structure and evolution and a host of other interesting areas $[31,46,47,48,31,46-48]$. The in-situ methods involve the use of DNA or RNA probes, which are labelled with fluorescent molecules and hybridized to genomic DNA sequences, to enable the study of specific sites on chromosomes. The advancement in the available technology continuously provides scientists with more robust variants of the technique with more resolution. Below we discuss some of the most applied variants currently.

The production of probes, which is achieved through DNA extraction and labelling is the first step in FISH. The labelling could be done by either PCR, random priming or enzymatically through nick translation.

Nick translation is a process by which DNA polymerase causes nicks in single DNA strands through its exonuclease activity. Thereafter, nucleotide, which are labelled with fluorescent dye are incorporated in to the broken single strands, the nicks, by DNA polymerases. The polymerase uses the healthy strand, which is non-nicked as a template.

The first step in FISH is production of a DNA probe. This is achieved by incorporating a fluorochrome into a template the DNA in a reaction known as labelling. The probes can be labelled by a number of different reactions, these could be achieved through both enzymatic and chemical procedures. as nick translation, random priming or the polymerase chain reaction (PCR). After a probe is produced from genomic DNA, Cot-1 DNA, which suppress the hybridization of repetitive sequences, is added to the mixture, to prevent non-specific hybridization, which can in difficulty to distinguish between 'signal' and 'background noise' [49].

Slides of metaphase chromosome spreads are prepared as described above [50]. The slide is heated appropriately to denature the target DNA. The probe, which is mixed with the and Cot-1 DNA is also denatured by heating and thereafter applied to the slide for hybridization. 


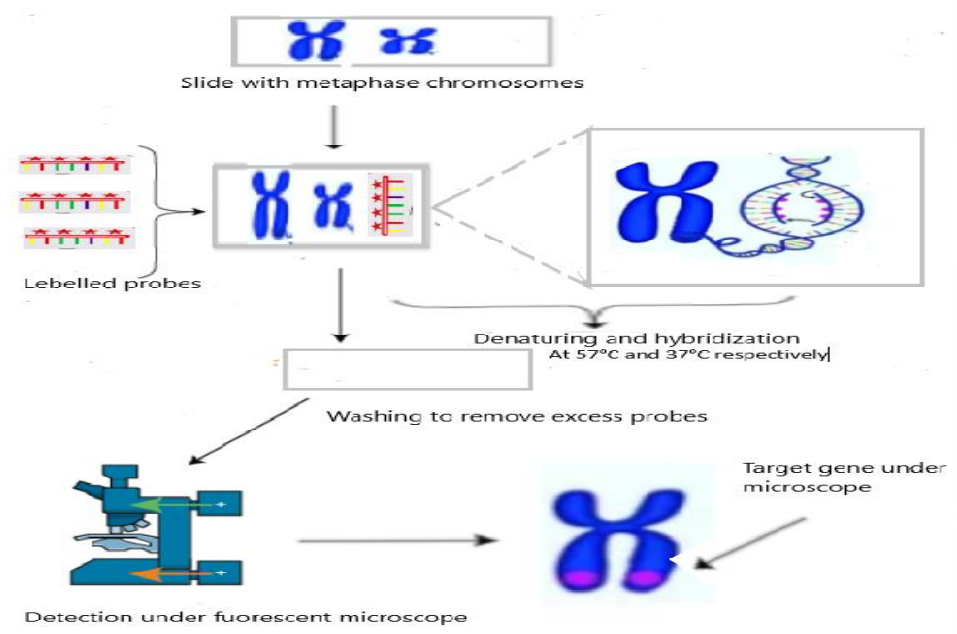

Fig. 3. Steps involved in FISH

Source: Theriogenology and cytogenetic laboratory UPM, 2019

The slide is incubation for an average of period of 24 hours at $37^{\circ} \mathrm{C}$ for hybridization between the probe and target DNA [49]. The length of hybridization sequences determines the incubation time, generally shorter probes, like repetitive DNA probes or chromosome-painting probes, require shorter incubation time, whereas longer probes, require longer incubation time [49]. The target is detected under fluorescent microscope [1] (Fig. 3).

\subsection{Spectral Karyotyping and Multicolor Fish (M-Fish)}

The advent of FISH saw the birth of a technique which allows the fluorescence of a single copy gene at a time. This was a very big improvement at the time, but researchers soon began longing for even more potent techniques that could paint multiple chromosomes and genes at the same time [31]. To achieve this, a technique called $\mathrm{M}$ FISH was developed in humans [51]. M-FISH enabled the painting and viewing of all the human chromosome in different colours at the same time. In this technique every chromosome can have a different color through the combination of fluorescent dyes at in different concentrations. This technique can be useful, especially in the case of complex aberrations associated with solid tumors of different types [5]. These techniques can be made to automatically stratify different chromosomal segments by differential coloration. The presence of this and its enhancements signal a new down in the hope for automated karyotype analysis system in the near future [45,52]. M-FISH techniques have proven a lot of usefulness in detecting chromosomal translocations and other intricate chromosomal aberrations [1]. To avoid fertilization failure due to chromosomal abnormality after IVF, MFISH is employed to screen the oocytes, in humans, to ensure that oocytes with no chromosomal abnormality are used in the procedure. This is called Preimplantation Genetic Diagnosis (PGD) screening [53]. This procedure should be useful in veterinary cytogenetics, especially with regards to endangered species [54].

The simultaneous hybridization of chromosomespecific composite probes is the basis on which SKY was build. For humans and mouse, probes are generated after sorting the chromosomes through flow cytometry [55]. Each chromosome library is generated by labelling them with single or a combination of multiple fluorochromes, which produce specific spectra for the chromosomes. To increase resolution and discernibility of the procedure, different combination of fluorochromes is preferred. For painting human chromosomes, five different fluorochromes are incorporated into the DNA through a combinative labelling program using degenerate oligonucleotide primer-polymerase chain reaction (DOP-PCR), it allows the identification of 31 different targets [49]. Repetitive sequences are a primary problem of this technique, therefore excess of Cot-1 DNA is used with the probes to suppress the unwanted sequences during hybridization onto metaphase chromosome preparations. The hybridization mixture is incubated at $37^{\circ} \mathrm{C}$ for an average of 48 


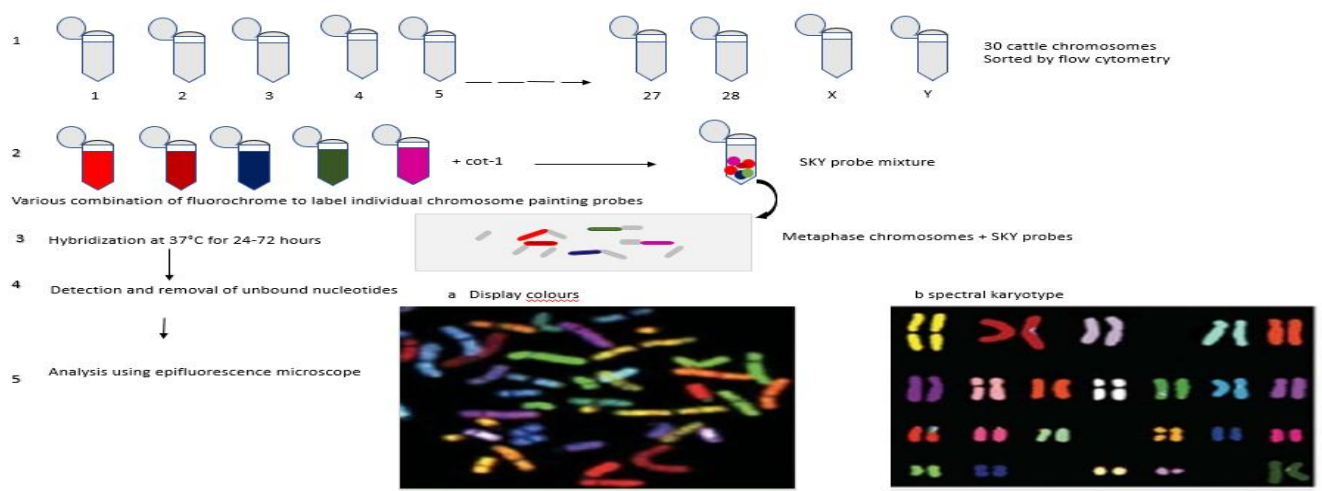

Fig. 4. Spectral karyotyping

Source: Theriogenology and cytogenetic laboratory UPM, 2019

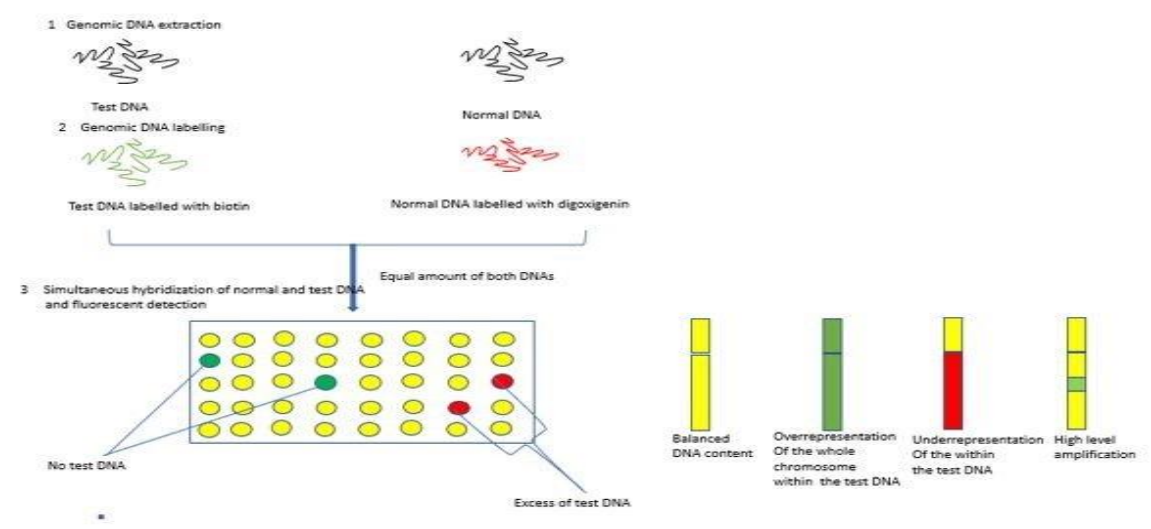

Fig. 5. Comparative genomic hybridization

Source: Theriogenology and cytogenetic laboratory UPM, 2019

hours. Post hybridization washes are used to remove residual probes before detection steps are to visualize the specimens [49]. The detection is achieved by Image acquisition and processing using a complex microscope system and a CCD camera with interferometer and a computer [15]. The spectral signatures are measured at all image points, all pixels with identical spectra are assigned unique colors and this measurement is used for chromosome classification [28,56]. With this technique, specific colour are assigned to each chromosome and the image is acquired with a single filter set [55] (Fig. 4).

\subsection{Comparative Genomic Hybridization (Cgh)}

$\mathrm{CGH}$, and its later variants, which are more robust than $\mathrm{FISH}$, have been employed to address its complexities and automation challenges [57]. Because of its ability to detect various types of genetic imbalances in a single experiment, $\mathrm{CGH}$ has become a very useful and widely employed tool in cytological techniques in recent times [49].

One of the most important advantages of $\mathrm{CGH}$ is that it does not require slides of metaphase chromosomes, it is used to survey DNA copy number variation, with vary high resolution across the genome [58,59,60,58-60]. In CGH well characterized probes are printed on slides and DNA samples; unknown and control, which are differentially labeled are hybridized to the slide. The ratio of the unknown DNA to that of the control are analyzed and measured [61].

$\mathrm{CGH}$ is applied to the whole genome; the entire genomic DNA of the test and reference are obtained by standard DNA extraction protocols. The two DNAs are labelled with different labelling 
agents (for example biotin for the test genome and digoxigenin reference genome). The two DNAs are combined and added to an unlabeled cot-1 DNA, to rid both genomes of unwanted repetitive sequences $[31,62]$. The mixture is mapped to a reference metaphase slide, which carries a normal DNA, through hybridization. The two DNAs are detected using Avidin coupled with FITC and antidigoxin coupled to rhodamine for biotin and digoxigenin-labelled DNA respectively. The DNA copy-number alterations in the test genome is detected by the different colour intensities. The two fluorochromes allows the copy number alteration in the test DNA to be detected [49].

\subsection{Micronucleus Assay}

Another important cytogenetic technique is the micronucleus assay ( $\mathrm{MN}$ assay), which is a genotoxic assay commonly employed to test animals exposed to chemicals. A micronucleus is a cytoplasmic body with a portion of chromosome, either acentric or whole that was not migrated to opposite poles during mitosis or meiosis [63]. As a result of micronuclei formation, resultant daughter cells from cell divisions end up with chromosomal aneuploidy, while the micronuclei develop nuclear membranes and become a third nucleus [64,65]. With more genetic damage, there is usually more than one micronucleus formed. This usually occurs as a result of nuclear damage by mutagens (Fig. 6). The MN assay is therefore suitable for and frequently employed in toxicological screening of chemicals with potential genotoxicity,to assess chromosomal damage as a result of their exposure to these genotoxins $[65,66]$. This has for quite a long time been recognized as one of the most successful and reliable assays for detecting the effects of mutagens in chemical compounds [64]. The technique is adopted and recommended by theOrganization for Economic Co-operation and Development (OECD) guideline as the gold standard for chemical testing [67]. During this assay the micronuclei, which are chromosomes or chromosomal fragments that become separated during mitosis, are detected and scored using image analysis [68]. Two major forms of the test exist and are widely used today; the in vivo and the in vitro forms [69]. Mouse peripheral blood or bone marrow are the two most commonly used tissues in the in vivo test [70]. Micronucleus assay in the cells of the bone marrow is based on the principle that polychromatic erythrocytes develop from erythroblasts with a resultant extrusion of the main nucleus and therefore leaving behind anucleated cytoplasm. Therefore if any micronucleus is formed then it will remain behind in the cytoplasm [66]. As would be expected the in vitro form of the assay is carried out on cultured cells.Evans et al., used micronuclei to study chromosomal damage in root of the fava bean, (Vicia faba) for the first time [71]. In a subsequent, independent development, W. Schmid and by J.A. Heddle and their colleagues introduced the in vivo assay [66], whereas J.T. MacGregor developed the mouse peripheral blood assay [72]. Tometsko et al., adapted the test for measurement through the use of flow cytometry [66]. The in vitro version of the test, which was in cultured cells was developed by J.A. Heddle et al., in human lymphocytes $[73,74]$. In the following years, the in vitro version of this assay witnessed a great deal of improvement by M. Fenechfor use in lymphocytes and other cells in culture cells $[73,74]$.

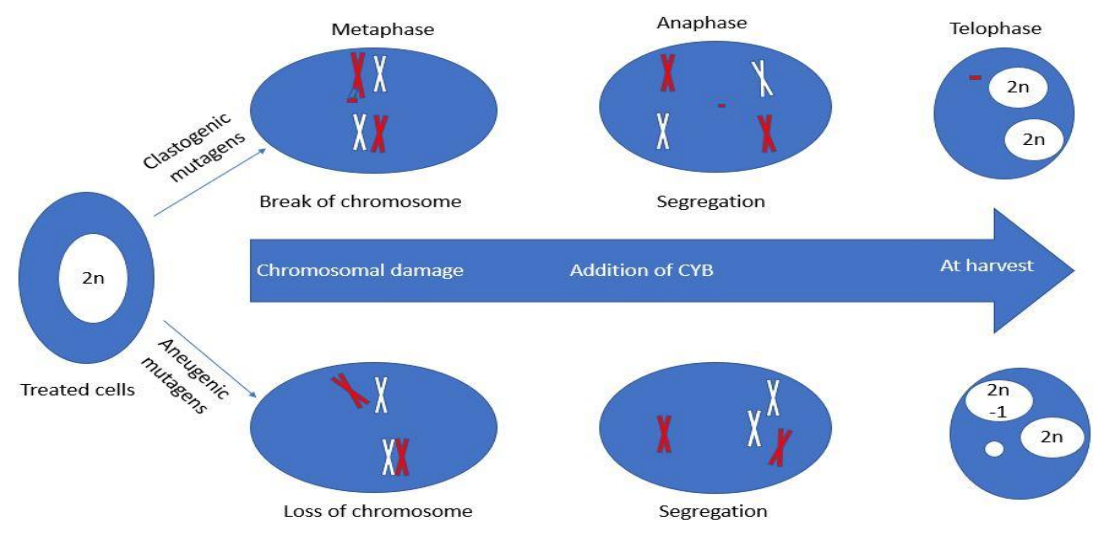

Fig. 6. Steps in micronucleus formation and its detection Source: Theriogenology and cytogenetic laboratory UPM, 2019 


\subsection{Telomere Length Analysis}

Another technique which is important in animal production is telomere analysis. The structures are located at chromosomes terminals and in conjunction with some proteins (TRF1, TRF2, POT1, TIN2, TPP1 and Rap1) protect the chromosomes from deterioration at the extremities and fusion with neighboring chromosomes [75]. Because telomeres undergo shortening during replication in livestock and humans [76], analysis of its length has the potential to be used as a marker for diagnosis, especially for stress $[16,77,78,79,16,77-79]$. Shortening of telomere is also associated with oxidative stress, resulting from inflammation or exposure to xenobiotics or irradiation [80].

Current techniques employed to study telomere length include quantitative fluorescence in situ hybridization (Q-FISH), PCR of single telomere lengths (STELA), qPCR, interphase nuclei and flow-FISH and terminal restriction fragment (TRF) length analysis by Southern blot $[81,82]$.

\subsection{Immunolocalization of DNA Repair Proteins}

This is another technique applied to animal production, it has been used to study chromosome pairing chromosome translocation and recombination during meiosis [83]. It has also been applied for the study double strand DNA breaks via histones and binding proteins [84]. This analysis can be achieved without necessarily making slide that will require protein fixation $[85,86]$.

\subsection{Comet Assay}

Through this test researchers can study single cells to evaluate DNA strand breaks therein, it is also known as single cell gel electrophoresis. Cell are lysed in neural or alkaline condition and then they are embedded in a low melting agarose gel. The suspended cells are electrophoresed and stained with fluorescent DNA dye and imaged. Undamaged cells are highly organized and show slow migration across the gel, while damaged ones don't appear organized and migrate faster along the gel. Double-strand breaks are identified in neutral conditions, while alkaline conditions allow double-strand breaks detection $[87,88]$. The technique has been used to study various toxicological effects in humans and livestock [8992] in cattle; [93] in sheep and [94] in horses.

\section{CONCLUSION}

Cytogenetics has had great importance in veterinary reproduction over the past few decades since its introduction and the application has greatly increased our understanding of animal infertility and its types, embryonic and fetal death, abnormality in sexual and somatic development and hybrid sterility and also prenatal sex determination and chromosomal abnormality. The Molecular techniques have greatly enhanced the field of cytogenetic research. The development of FISH techniques has, particularly widened the paradigm for research in this area considerably. The existence of enormous resolution gap between traditional cytogenetic techniques and molecular biology techniques has now been extensively reduced by molecular cytogenetics. Scientists have successfully arrested the problem of sensitivity by developing new methods which have the ability to detect fluorescently labeled probes not more than 200 base pairs length. Another feat is the development of MFISH, which enables colour karyotyping, and therefore, the simultaneous visualization of a complete set of chromosomes. This has greatly reduced the issue of multiplicity in these techniques. Characterization of imbalances in chromosomes is today conveniently, thanks to the introduction of $\mathrm{CGH}$, which has become an invaluable tool in this regard. The Comet assay, Immunolocalization of DNA repair proteins and Telomere length analysis have all played various roles in shaping our understanding of cytogenetics today. These advances have together contributed in improving and refining the field of cytogenetics and have increased the ease and versatility of research using cytogenetic tools. The applications of these techniques have now transcended the boundaries of low-resolution diagnostics of chromosomal aberrations and is now well established in functional and comparative basic research.

\section{COMPETING INTERESTS}

Authors have declared that no competing interests exist.

\section{REFERENCES}

1. Speicher MR, Carter NP. The new cytogenetics: Blurring the boundaries with molecular biology. Nat Rev Genet [Internet]. 2005;6(10):782-92.

Available:http://www.ncbi.nlm.nih.gov/pub $\mathrm{med} / 16145555$ 
2. Gustavsson I, Rockborn G. Chromosome abnormality in three cases of lymphatic leukaemia in cattle. Nature. 1964;203(1): 990.

3. Dyrendhal I, Gustavsson I. Sexual functions, semen characteristics and fertility of bulls carrying the $1 / 29$ chromosome translocation. Hereditas. 1979; 90(2):281-9.

4. Demyda-Peyrás $S$, Membrillo A, BugnoPoniewierska M, Pawlina K, Anaya G, Moreno-Millán $M$. The use of molecular and cytogenetic methods as a valuable tool in the detection of chromosomal abnormalities in horses: A case of sex chromosome chimerism in a spanish purebred colt. Cytogenet Genome Res [Internet]. 2013;141(4):277-83.

[Cited 2019 Mar 2]

Available:http://www.ncbi.nlm.nih.gov/pub $\mathrm{med} / 23735586$

5. lannuzzi L, Villagómez DAF, King WA. Preface. cytogenet genome res [Internet]. 2009;126(1-2):5-6.

[cited 2017 Dec 30]

Available:http://www.ncbi.nlm.nih.gov/pub $\mathrm{med} / 20016151$

6. lannuzzi IG. R-banded promethaphase karyotypes in cattle (Bos taurus L.). Chromosom Res. 1996;4(1):448-56.

7. Ford CE, Pollok DL GI. Reading conference. In: Ford CE, Pollok DL GI, editor. Proceedings of the First International Conference for the Standardization of Banded Karyotypes of Domestic Animals. Reading; 1980;145-62.

8. Di Berardino D, Burguete I. High resolution RBA-banding comparison between early prometaphase chromosomes of cattle (Bos taurus L.) and goat (Capra hircus L.) at 700 band level. Cytogenet Genome Res. 2003;83(1-2):130-8.

9. El-Bayomi KM, EL-Araby IES, Zaglool AW. Cytogenetic analysis related to some infertility problems in Cattle. Glob Vet. 2011;7(4):323-9.

10. Naha BC, Prakesh C, Boro P. Review article application of cytogenetic techniques in livestock. Int J Sci Nat. 2016;7(1): 30-3.

11. Serakinci N, Kølvraa S. Molecular cytogenetic applications in diagnostics and research: An overview. Fluoresc Situ Hybrid - Appl Guid. 2009;3-21.

12. Hayes $H$, Dutrillaux $B$, Popescu $P$, Bourgeois C. Chromosome banding techniques. In 2000;25-68.
[Cited 2017 Apr 15]

Available:http://link.springer.com/10.1007/9 78-3-642-59711-4_2

13. Gall JG, Pardue ML. Formation and detection of RNA-DNA hybrid molecules in cytological preparations. Proc Natl Acad Sci USA. 1969;63(1):378-383.

14. Blagodatskikh KA, Kramarov VM, Barsova EV, Garkovenko AV, Shcherbo DS, Shelenkov AA, et al. Improved DOP-PCR (iDOP-PCR): A robust and simple WGA method for efficient amplification of low copy number genomic DNA. Kalendar R, editor. PLoS One [Internet]. 2017;12(9): e0184507.

[Cited 2019 Mar 6]

Available:https://dx.plos.org/10.1371/journ al.pone.0184507

15. Wnuk M, Bugno M, Slota E. Application of primed in situ DNA synthesis (PRINS) with telomere human commercial kit in molecular cytogenetics of Equus caballus and Sus scrofa scrofa. Folia Histochem Cytobiol. 2008;46(1):85-8.

16. Fouquerel E, Parikh D, Opresko P. DNA damage processing at telomeres: The ends justify the means. DNA Repair (Amst) [Internet]. 2016;44:159-68.

17. Available:http://dx.doi.org/10.1016/j.dnarep .2016.05.022

18. Barnes RP, Fouquerel E, Opresko PL. The impact of oxidative DNA damage and stress on telomere homeostasis. Mech Ageing Dev [Internet]. 2019;177:37-45.

Available:https://doi.org/10.1016/j.mad.201 8.03.013

19. De Lorenzi L, Morando P, Planas J, Zannotti M, Molteni L, Parma P. Reciprocal translocations in cattle: Frequency estimation. J Anim Breed Genet [Internet]. 2012;129(5):409-16.

[Cited 2019 Mar 6]

Available:http://www.ncbi.nlm.nih.gov/pub $\mathrm{med} / 22963362$

20. Gustavsson I. Cytogenetics, distribution and phenotypic effects of a translocation in Swedish cattle. Hereditas. 1969;63(1):68169.

21. Avila F, Das PJ, Kutzler M, Owens E, Perelman P, Rubes J, et al. Development and application of camelid molecular cytogenetic tools. J Hered [Internet]. 2014;105(6):952-63.

Available:http://10.0.4.69/jhered/ess067

22. Nakaya $M$, Tanabe $H$, Takamatsu $S$, Hosokawa M, Mitani T. Visualization of the spatial arrangement of nuclear organiza- 
tion using three-dimensional fluorescence \&lt;i\&gt;in situ\&lt;/i\&gt; hybridization in early mouse embryos: A new "EASI-FISH chamber glass" for mammalian embryos. J Reprod Dev [Internet]. 2017;63(2):167-74. [Cited 2019 Mar 5]

Available:http://www.ncbi.nlm.nih.gov/pub $\mathrm{med} / 28190810$

23. Stomornjak-Vukadin M, Kurtovic-Basic I, Mehinovic L, Konjhodzic R. Combined use of cytogenetic and molecular methods in prenatal diagnostics of chromosomal abnormalities. Acta Inform Med [Internet]. 2015;23(2):68-72.

[Cited 2019 Mar 6]

Available:http://www.ncbi.nlm.nih.gov/pub $\mathrm{med} / 26005269$

24. Zudova D, Rezacova O, Kubickova S, Rubes J. Aneuploidy detection in porcine embryos using fluorescence in situ hybridization. Cytogenet Genome Res [Internet]. 2003;102(1-4):179-83.

[Cited 2017 Dec 30]

Available:http://www.ncbi.nlm.nih.gov/pub med/14970699

25. Foster HA, Sturmey RG, Stokes PJ, Leese HJ, Bridger JM GD. Fluorescence in situ hybridization on early porcine embryos. Methods Mol Biol. 2010;659(1):427-36.

26. Mary N, Barasc H, Ferchaud S, Billon $\mathrm{Y}$, Meslier F, Robelin D, et al. Meiotic recombination analyses of individual chromosomes in male domestic pigs (Sus scrofa domestica). Shi $Q$, editor. PLoS One [Internet]. 2014;9(6):e99123.

[Cited 2017 Dec 30]

Available:http://www.ncbi.nlm.nih.gov/pub med/24919066

27. Perkins AT, Bickel SE. Using fluorescence in situ</em> hybridization $(\mathrm{FISH})$ to monitor the state of arm cohesion in prometaphase and metaphase i <em> drosophila</em $>$ oocytes. J Vis Exp [Internet]. 2017;130.

Available:https://www.jove.com/video/5680 2/using-fluorescence-situ-hybridizationfish-to-monitor-state-arm

28. King WA. Chromosome variation in the embryos of domestic animals. Cytogenet Genome Res [Internet]. 2008;120(1-2):8190.

[Cited 2017 Dec 30]

Available:http://www.ncbi.nlm.nih.gov/pub $\mathrm{med} / 18467828$

29. Bugno $M$, Jabłońska $Z$, Słota $E$. Optimalization of fluorescence in situ hybridization conditions in mare oocytes and mouse embryos. Folia Biol (Praha) [Internet]. 2009;57(1-2):49-55.

[Cited 2017 Dec 30]

Available:http://www.ncbi.nlm.nih.gov/pub $\mathrm{med} / 19459461$

30. lannuzzi L, King WA, Di Berardino D. Chromosome evolution in domestic bovids as revealed by chromosome banding and fish-mapping techniques [Internet]. Cytogenetic and Genome Research. 2009; 126:49-62.

[cited 2017 Dec 30]

Available:http://www.ncbi.nlm.nih.gov/pub $\mathrm{med} / 20016156$

31. Issa ÉC, Jorge W, Sereno JRB. Cytogenetic and molecular analysis of the Pantaneiro cattle breed. Pesqui Agropecu Bras. 2006;41(11):1609-15.

32. Genualdo V, Spalenza V, Perucatti A, lannuzzi A, Di Meo GP, Caputi-Jambrenghi $A$, et al. Fluorescence in situ hybridization mapping of six loci containing genes involved in the dioxin metabolism of domestic bovids. J Appl Genet. 2011; 52(2):229-32.

33. Bugno-Poniewierska $M$, Sołek $P$, Potocki L, Pawlina K, Wnuk M, JezewskaWitkowska G, et al. Polymorphism of cytogenetic markers in wild and farm red fox (Vulpes vulpes) populations. Folia Biol (Praha) [Internet]. 2013;61(3-4):15563.

[Cited 2017 Dec 30]

Available:http://www.ncbi.nlm.nih.gov/pub $\mathrm{med} / 24279163$

34. McPherson MC, Robinson CM, Gehlen LP, Delany ME. Comparative cytogenomics of poultry: Mapping of single gene and repeat loci in the Japanese quail (Coturnix japonica). Chromosom Res [Internet]. 2014;22(1):71-83.

[Cited 2017 Dec 30]

Available:http://www.ncbi.nlm.nih.gov/pub $\mathrm{med} / 24604153$

35. Schmid M, Steinlein C. Chromosome banding in amphibia. XXXII. The Genus Xenopus (Anura, Pipidae). Cytogenet Genome Res [Internet]. 2015;145(34):201-17.

[Cited 2017 Apr 15]

Available:http://www.ncbi.nlm.nih.gov/pub $\mathrm{med} / 26112092$

36. Sessions SK, Stöck $M$, Vieites $D R$, Quarles R, Min MS, Wake DB. Cytogenetic analysis of the Asian Plethodontid salamander, Karsenia koreana: Evidence for karyotypic conservation, chromosome 
repatterning, and genome size evolution. Chromosom Res. 2008;16(4):563-74.

37. McKinney S, Guerrero-Hernández C, Guo L, Gibson M, Accorsi A, Sivagnanam S, et al. An adaptable chromosome preparation methodology for use in invertebrate research organisms. BMC Biol [Internet]. 2018;16(1):25.

[Cited 2019 Mar 5]

Available:http://www.ncbi.nlm.nih.gov/pub med/29482548

38. Zhao D, Liu S, Guo Z, Li R. [Application of eight-probe fluorescence in situ hybridization and R-banding karyotype analysis for the diagnosis of acute lymphoblastic leukemia]. Zhonghua Yi Xue $\mathrm{Yi}$ Chuan Xue Za Zhi [Internet]. 2016;33(1):9-12.

[Cited 2019 Mar 13]

Available:http://www.ncbi.nlm.nih.gov/pub $\mathrm{med} / 26829724$

39. Huang $\mathrm{H}$, Chen J. Chromosome bandings. Methods Mol Biol [Internet]. 2017;1541:5966.

[Cited 2019 Mar 13]

Available:http://www.ncbi.nlm.nih.gov/pub $\mathrm{med} / 27910014$

40. Lindner LE. Improvements in the silverstaining technique for nucleolar organizer regions (AgNOR). J Histochem Cytochem. 1993;41(3):439-45.

41. Trerè D. AgNOR staining and quantification. Micron [Internet]. 2000;31(2):12731.

[Cited 2019 Aug 22]

Available:http://www.ncbi.nlm.nih.gov/pub $\mathrm{med} / 10588058$

42. Bukhari MH, Niazi S, Khan SA, Hashmi I, Perveen S, Qureshi SS, et al. Modified method of AgNOR staining for tissue and interpretation in histopathology. Int J Exp Pathol [Internet]. 2007;88(1):47-53.

[Cited 2019 Aug 22]

Available:http://www.ncbi.nlm.nih.gov/pub $\mathrm{med} / 17244338$

43. Zheng JS, Sun CZ, Zhang SN, Hou XL, Bonnema G. Cytogenetic diversity of simple sequences repeats in morphotypes of Brassica rapa ssp. chinensis. Front Plant Sci [Internet]. 2016;7:1049.

[Cited 2019 Mar 5]

Available:http://www.ncbi.nlm.nih.gov/pub med/27507974

44. Rubes J, Pinton A, Bonnet-Garnier A, Fillon V, Musilova $\mathrm{P}$, Michalova $\mathrm{K}$, et al. Fluorescence in situ hybridization applied to domestic animal cytogenetics. Cyto- genet Genome Res [Internet]. 2009; 126(1-2):34-48.

[Cited 2017 Dec 28]

Available:http://www.ncbi.nlm.nih.gov/pub med/20016155

45. Artigas $\mathrm{R}$, Iriarte A, Tellechea B, Llambí S, De Bethencourt $M$, Postiglioni $A$. Aphidicolin induces break points in heterozygous Robertsonian translocation rob(1;29) from Uruguayan Creole cattle: Brief post. BAG - J Basic Appl Genet. 2008;19(1):1-8.

46. McNeil N, Ried T. Novel molecular cytogenetic techniques for identifying complex chromosomal rearrangements: technology and applications in molecular medicine. Expert Rev Mol Med [Internet]. 2000;1-14.

Available:http://www.ncbi.nlm.nih.gov/pub med/14585138

47. Hanada $H$. Robertsonian translocation and its effect on fertility in Japanese Black Cattle. Jarq. 1994;28(3):206-11.

48. Aricò $A$, Ferraresso $S$, Bresolin $S$, Marconato L, Comazzi S, Te Kronnie G, et al. Array-based comparative genomic hybridization analysis reveals chromosomal copy number aberrations associated with clinical outcome in canine diffuse large Bcell lymphoma. PLoS One [Internet]. 2014; 9(11):e111817.

[Cited 2019 Mar 5]

Available:http://www.ncbi.nlm.nih.gov/pub $\mathrm{med} / 25372838$

49. Perucatti A, lannuzzi A, Genualdo V, Incarnato D, Session P, Road M, et al. $21^{\text {st }}$ International colloquium on animal cyto-genetics and gene mapping. Chromosom Res [Internet]. 2014;22(3): 393-437.

Available:http://link.springer.com/10.1007/s 10577-014-9435-7

50. Tobergte DR, Curtis S. Fluorescence in situ Hybridization (FISH). Journal of Chemical Information and Modeling. 2013; 53:1689-1699.

51. Hayes $H$, Dutrillaux B, Popescu P. Preparation of chromosome spreads. In 2000;1-24.

[Cited 2017 Apr 15]

Available:http://link.springer.com/10.1007/9 78-3-642-59711-4_1

52. Geigl JB, Uhrig S, Speicher MR. Multiplexfluorescence in situ hybridization for chromosome karyotyping. Nat Protoc [Internet]. 2006;1(3):1172-84.

[Cited 2019 Sep 4] 
Available:http://www.ncbi.nlm.nih.gov/pub $\mathrm{med} / 17406400$

53. Mateos-Langerak J, Bohn M, de Leeuw W, Giromus O, Manders EMM, Verschure PJ, et al. Spatially confined folding of chromatin in the interphase nucleus. Proc Natl Acad Sci [Internet]. 2009;106(10): 3812-7.

Available:http://www.pnas.org/cgi/doi/10.10 73/pnas.0809501106

54. Ye $Y, X u C$, Jin F, Qian $Y$. Identification of embryonic chromosomal abnormality using FISH-based preimplantation genetic diagnosis. J Zhejiang Univ Sci [Internet]. 2004;5(10):1249-54.

[Cited 2019 Sep 4]

Available:http://www.ncbi.nlm.nih.gov/pub $\mathrm{med} / 15362197$

55. Lawce HJ. Chromosome stains. AGT Cytogenet Lab Man [Internet]. 2017;213300.

Available:http://doi.wiley.com/10.1002/978 1119061199.ch6

56. Mcneil N, Montagna C, Difilippantonio MJ, Ried T. Comparative cancer cytogenetics. Cancer. 2010;(Cml):1-22.

57. Bogdanovska-Todorovska M, Petrushevska G, Janevska V, Spasevska L, Kostadinova-Kunovska S. Standardization and optimization of fluorescence in situ hybridization (FISH) for HER-2 assessment in breast cancer: A single center experience. Bosn J basic Med Sci [Internet]. 2018;18(2):132-40.

[Cited 2019 Mar 5]

Available:http://www.ncbi.nlm.nih.gov/pub $\mathrm{med} / 29389309$

58. Kearney L. Multiplex-FISH (M-FISH): technique, developments and applications. Cytogenet Genome Res. 2006;114:189_ 198.

59. Houldsworth J, Chaganti RS. Comparative genomic hybridization: an overview. Am J Pathol [Internet]. 1994;145(6):1253-60.

[Cited 2018 Sep 25]

Available:http://www.ncbi.nlm.nih.gov/pub med/7992829

60. Yu W, Ballif BC, Kashork CD, Heilstedt HA, Howard LA, Cai WW, et al. Development of a comparative genomic hybridization microarray and demonstration of its utility with 25 well-characterized 1 p36 deletions. Hum Mol Genet. 2003; 12(17):2145-52.

61. Albertson DG, Pinkel D. Comparative genomic hybridization. Mol Oncol Causes Cancer Targets Treat. 2015;21-7.
62. Kowalska A, Bozsaky E, Ambros PF. Sequence-based high resolution chromosomal comparative genomic hybridization (CGH). In 2010;299-312.

[Cited 2017 Apr 15]

Available:http://link.springer.com/10.1007/9 78-1-60761-789-1_23

63. Shemetun OV, Talan OA, Demchenko OM, Kurinnyi DA, Papuga MS, Pilinska MA. Frequency of spontaneous and radiationinduced chromosomal aberrations in peripheral blood lymphocytes of individuals of different ages. Cytol Genet [Internet]. 2018;52(6):461-6.

Available:http://link.springer.com/10.3103/ S0095452718060117

64. Luzhna L, Kathiria P, Kovalchuk O. Micronuclei in genotoxicity assessment: From genetics to epigenetics and beyond. Front Genet. 2013;4:1-17.

65. Dixit M, Kumar A. Chapter 4 - In vitro gene genotoxicity test methods. In: Dhawan A, Kwon S, editors. In vitro Toxicology [Internet]. Academic Press. 2018;67-89. Available:http://www.sciencedirect.com/sci ence/article/pii/B9780128046678000043

66. Soto M, García-Santisteban I, Krenning L, Medema RH, Raaijmakers JA. Chromosomes trapped in micronuclei are liable to segregation errors. J Cell Sci [Internet]. 2018;131(13).

[Cited 2019 Sep 3]

Available:http://www.ncbi.nlm.nih.gov/pub $\mathrm{med} / 29930083$

67. Hayashi M. The micronucleus test-most widely used in vivo genotoxicity test. Genes Environ [Internet]. 2016;38(1):4-9. Available:http://dx.doi.org/10.1186/s41021016-0044-X

68. Oecd. OECD Test Guideline 487. 2014;126.

Available:https://ntp.niehs.nih.gov/iccvam/s uppdocs/feddocs/oecd/oecd-tg487-2014508.pdf

69. Darzynkiewicz Z, Smolewski P, Holden E, Luther E, Henriksen M, François $M$, et al. Laser scanning cytometry for automation of the micronucleus assay. Mutagenesis [Internet]. 2011;26(1):153-61.

[Cited 2019 Sep 3]

Available:http://www.ncbi.nlm.nih.gov/pub $\mathrm{med} / 21164197$

70. Corvi R, Madia F. In vitro genotoxicity testing-can the performance be enhanced? Food Chem Toxicol [Internet]. 2017;106:600-8.

[Cited 2019 Sep 3] 
Available:https://www.sciencedirect.com/sc ience/article/pii/S0278691516302903

71. Morita T, MacGregor JT, Hayashi M. Micronucleus assays in rodent tissues other than bone marrow. Mutagenesis [Internet]. 2011;26(1):223-30.

[Cited 2019 Sep 3]

Available:https://academic.oup.com/mutag e/article-lookup/doi/10.1093/mutage/ geq066

72. Hayashi M. In vivo rodent micronucleus assay. In: Chromosomal Alterations [Internet]. Berlin, Heidelberg: Springer Berlin Heidelberg. 2007;257-70.

[Cited 2019 Sep 3]

Available:http://link.springer.com/10.1007/9 78-3-540-71414-9_16

73. Kovac JR, Pastuszak AW, Lamb DJ. The use of genomics, proteomics, and metabolomics in identifying biomarkers of male infertility. In: Fertility and Sterility; 2013.

74. Aghamohammadi SZ, Henderson L, Cole RJ. The human lymphocyte micronucleus assay: Response of cord blood lymphocytes to $\mathrm{y}$-irradiation and bleomycin. Mutat Res Mutagen Relat Subj [Internet]. 1984;130(6):395-401.

[Cited 2019 Sep 3]

Available:https://www.sciencedirect.com/sc ience/article/pii/0165116184900116

75. Fenech M, Morley AA. Measurement of micronuclei in lymphocytes. Mutat Res Mutagen Relat Subj [Internet]. 1985; 147(1-2):29-36.

[Cited 2019 Sep 3]

Available:https://www.sciencedirect.com/sc ience/article/pii/0165116185900159?imgS el $=Y$

76. Udroiu I, Sgura A. Cytogenetic tests for animal production: State of the art and perspectives. Anim Genet. 2017;48(5): 505-15.

77. Gomes NMV, Ryder OA, Houck ML, Charter SJ, Walker W, Forsyth NR, et al. Comparative biology of mammalian telomeres: Hypotheses on ancestral states and the roles of telomeres in longevity determination. Aging Cell [Internet]. 2011;10(5):761-8.

[Cited 2019 Mar 4]

Available:http://www.ncbi.nlm.nih.gov/pub med/21518243

78. Alexander P. Sobinoff, Hilda A. Pickett. Alternative Lengthening of telomeres: DNA Repair pathways converge. Trends Genet [Internet]. 2017;33(12):921-32.
Available:http://dx.doi.org/10.1016/j.tig.201 7.09.003

79. Bateson M. Cumulative stress in research animals: Telomere attrition as a biomarker in a welfare context? BioEssays. 2016; 38(2):201-12.

80. Yamakawa RH, Saito PK, Gelmini GF, da Silva JS, Bicalho M da G, Borelli SD. MICA diversity and linkage disequilibrium with HLA-B alleles in renal-transplant candidates in southern Brazil. Song $Q$, editor. PLoS One [Internet]. 2017;12(4):e0176072.

[Cited 2017 May 21]

Available:http://www.ncbi.nlm.nih.gov/pub $\mathrm{med} / 28419176$

81. Von Zglinicki T. Oxidative stress shortens telomeres. Trends Biochem Sci. 2002; 27(7):339-44.

82. Jenkins FJ, Kerr CM, Fouquerel E, Bovbjerg DH, Opresko PL. Modified terminal restriction fragment analysis for quantifying telomere length using in-gel hybridization. J Vis Exp [Internet]. 2017; 125.

[Cited 2019 Aug 22]

Available:http://www.ncbi.nlm.nih.gov/pub $\mathrm{med} / 28715381$

83. Aubert G, Hills M, Lansdorp PM. Telomere length measurement-Caveats and a critical assessment of the available technologies and tools. Mutat Res Mol Mech Mutagen [Internet]. 2012;730(12):59-67.

[Cited 2019 Aug 22]

Available:https://www.sciencedirect.com/sc ience/article/pii/S0027510711000868?via $\% 3$ Dihub

84. Vozdova M, Ruiz-Herrera A, Fernandez J, Cernohorska $\mathrm{H}$, Frohlich J, Sebestova HKS, RJ. Meiotic behaviour of evolutionary sex-autosome translocations in Bovidae. Chromosom Res. 2016;24:325-38.

85. Rothkamm K, Barnard S, Moquet J, Ellender MRZ. BRS. DNA damage foci: Meaning and significance. Environ Mol Mutagen. 2015;56:491-504.

86. Masuda $Y$, Takahashi $H$, Sato $S$, Tomomori-Sato C, Saraf A, Washburn MP, et al. TRIM29 regulates the assembly of DNA repair proteins into damaged chromatin. Nat Commun [Internet]. 2015;6:1-13.

Available:http://dx.doi.org/10.1038/ncomm s8299

87. Berardinelli $F$, di Masi $A$, Salvatore $M$, Banerjee S, Myung K, De Villartay JP, et 
al. A case report of a patient with microcephaly, facial dysmorphism, chromosomal radiosensitivity and telomere length alterations closely resembling "Nijmegen breakage syndrome" phenotype. Eur J Med Genet. 2007;50(3):176-87.

88. Glei MST, SW. Comet assay: An essential tool in toxicological research. Arch Toxicol. 2016;90:2315-36.

89. Tice RR, Hartmann A, Sasaki YF, Rojas E, Anderson D, Miyamae Y, Agurell E, et al. Single cell gel/comet assay: Guidelines for in vitro and in vivo genetic toxicology testing. Environ Mol Mutagen. 2000;35(3): 206-21.

90. Gafter-Gvili A, Zingerman B, Rozen-Zvi B, Ori $Y$, Green H, Lubin I, et al. Oxidative stress-induced DNA damage and repair in human peripheral blood mononuclear cells: Protective role of hemoglobin. Maga G, editor. PLoS One [Internet]. 2013;8(7):e68341.

[Cited 2019 Mar 5]

Available:http://www.ncbi.nlm.nih.gov/pub $\mathrm{med} / 23874593$

91. Picco SJ, Abba MC, Mattioli GA, Fazzio LE, Rosa DDLJC, DFN. Association between copper deficiency and DNA damage in cattle. Mutagenesis. 2004;19: 453-6.

92. Di Meo GP, Perucatti A, Genualdo V, Caputi-Jambrenghi A, Rasero RNC. Chromosome fragility in dairy cows exposed to dioxins and dioxin-like PCBs. Mutagenesis. 2011;26:269-72.

93. Picco S, Ponzzinibio MV, Mattioli G, Rosa D, Minatel L, Fazzio L, et al. Physiological and genotoxic effects of molybdenuminduced copper deficiency in cattle. Agrociencia. 2012;46(2):107-17.

94. lannuzzi L, Perucatti A, Di Meo GP, Polimeno F, Ciotola F, Incarnato D, et al. Chromosome fragility in two sheep flocks exposed to dioxins during pasturage. Mutagenesis. 2004;19(5):355-9.

95. David J. Marlin, Lucy Johnson, Demelza A. Kingston, Nicola C. Smith, Chris M. Deaton, Sarah Mann, Paul Heaton, y Fenneke Van Vugt, Kelly Saunders, Julia Kydd and PAH. Application of the Comet assay for investigation of oxidative DNA damage in equine peripheral blood mononuclear cells. J Nutr. 2004;134(8): 2072S-2080S.

(c) 2019 Yahaya et al.; This is an Open Access article distributed under the terms of the Creative Commons Attribution License (http://creativecommons.org/licenses/by/4.0), which permits unrestricted use, distribution, and reproduction in any medium, provided the original work is properly cited.

Peer-review history:

The peer review history for this paper can be accessed here: http://www.sdiarticle3.com/review-history/51281 